\title{
Resistance of Pseudomonas anguilliseptica to Bactericidal Action of Fish Serum
}

\author{
Toshihiro NAKAI* \\ (Accepted January 28, 1985)
}

\begin{abstract}
Resistance of an eel pathogen Pseudomonas anguilliseptica to bactericidal action of fish sera was compared between $\mathrm{K}$ antigen-possessing $\left(\mathrm{K}^{+}\right)$and -lacking $\left(\mathrm{K}^{-}\right)$strains in connection with their pathogenicity. The $\mathrm{K}^{+}$strain displayed high resistance to the bactericidal action of Japanese eel, European eel, and bluegill sera, but not to carp, goldfish, rainbow trout, or tilapia sera, whereas the $\mathrm{K}^{-}$strain was highly sensitive to all sera. The pathogenicity tests proved that the former three species were susceptible to the virulent $\mathrm{K}^{+}$strain, but the latter four were not. Thus, the $\mathrm{K}$ antigen-related resistance to serum-killing corresponded with the pathogenicity of the organism. The bactericidal activity of fish serum was more effective at $28^{\circ} \mathrm{C}$ than at $20^{\circ} \mathrm{C}$, and was lost by heat-treatment at $50^{\circ} \mathrm{C}$ for $30 \mathrm{~min}$.
\end{abstract}

It is known that fish possess a complement system similar to that present in mammals. This complement system activated either by classical or alternative pathway plays an important role in the protection of nonimmune and immune fish against bacterial infections, as reviewed by INGRAM. ${ }^{1)}$ Recent reports suggested that the direct bactericidal reaction of serum (or complement) by the alternative pathway would be of particular importance in the protection of nonimmune fish. This means that the resistance of pathogens against bactericidal factor(s) of the host serum contributes to their pathogenicity or virulence. ${ }^{2-\theta)}$

Pseudomonas anguilliseptica is the pathogen of red spot disease of pond-cultured eels (Anguilla japonica and $A$. anguilla). ${ }^{7-10)}$ This systemic disease prevalis at lower water temperature (10$20^{\circ} \mathrm{C}$ ), especially in early spring, and ceases at $27^{\circ} \mathrm{C}$ or above in summer. ${ }^{11)}$ The previous serological studies on $P$. anguilliseptica revealed that virulent strains have a heat-labile surface antigen ( $\mathrm{K}$ antigen), which acts as an agglutinationinhibitory substance against rabbit $\mathrm{O}$-antiserum. ${ }^{12-15)}$ Analysis of the fate of $\mathrm{K}^{+}(\mathrm{K}$ antigenpossessing) and $\mathrm{K}^{-}$strains in vivo indicated that the ability to survive in the blood of Japanese eels might be a crucial factor for the virulence of the pathogen. ${ }^{1 \theta)}$

In the present study, the resistance of $P$. anguilliseptica to in vitro bactericidal action of sera of several fish species was compared between $\mathrm{K}^{+}$ and $\mathrm{K}^{-}$strains in connection with their pathogenicity to each fish.

\section{Materials and Methods}

\section{Fish and Serum Collection}

Seven freshwater fishes, Japanese eel ( $A$. japonica, mean weight: $105 \mathrm{~g})$, European eel $(A$. anguilla, $120 \mathrm{~g}$ ), bluegill (Lepomis macrochirus, $42 \mathrm{~g}$ ), carp (Cyprinus carpio, $175 \mathrm{~g}$ ), goldfish (Carassius auratus, 6g), tilapia (Sarotherodon niloticus, $40 \mathrm{~g}$ ), and rainbow trout (Salmo gairdneri, $165 \mathrm{~g}$ ) were used in this study. After acclimation at about $20^{\circ} \mathrm{C}\left(13^{\circ} \mathrm{C}\right.$ for rainbow trout) for a week, fish were bled from the dorsal aorta or bulbus arteriosus (eels) and the sera were separated by centrifugation at $3,000 \mathrm{~g}$ for $10 \mathrm{~min}$ at $4^{\circ} \mathrm{C}$. The pooled sera from 5 to 10 fish were stored in small portions at $4^{\circ} \mathrm{C}$ (usually used within $2 \mathrm{~h}$ ) or at $-80^{\circ} \mathrm{C}$ until required. In addition to these normal sera, immune Japanese eel and rabbit sera against formalinized cells of ET-7601 strain $\left(\mathrm{K}^{+}\right)$were also used. The homologous agglutinin titers of eel and rabbit immune sera were 256 and 512 , respectively.

\section{Bacterial Strains}

A total of 20 strains of $P$. anguilliseptica isolated from diseased eels in Japan, Scotland, and Taiwan, which consisted of $10 \mathrm{~K}^{+}$strains, $9 \mathrm{~K}^{-}$strains, and one intermediate type $\left(\mathrm{K}^{ \pm}\right)$strain, were employed. The $K$ antigen determination was done

* Faculty of Applied Biological Science, Hiroshima University, Fukuyama 720, Japan (中井敏博：広島大学 生物生産学部). 
by agglutination with rabbit anti-O serum and anti-K serum (Table 2). Anti-O serum was raised against heated cells (at $121^{\circ} \mathrm{C}$ for $30 \mathrm{~min}$ ) of ET-7601 strain. Anti-K serum was prepared by absorbing the anti-OK serum, which was raised against formalinized cells of ET-7601 strain, with formalinized cells of ET-2 strain (K-). Both ET-7601 and ET-2 strains were used in all experiments, while the others were only in experiments with Japanese eels.

\section{Bactericidal Assay}

Culture of $P$. anguilliseptica on nutrient agar at $20^{\circ} \mathrm{C}$ for 2 days were suspended in phosphate buffered saline (PBS, $\mathrm{pH}$ 7.2) at concentration of $1-2 \times 10^{8} \mathrm{CFU} / \mathrm{ml}$. One tenth $\mathrm{ml}$ of the cell suspension was added to $1.0 \mathrm{~m} l$ of fish serum undiluted or diluted with gelatin veronal buffer containing $\mathrm{Mg}^{++}$and $\mathrm{Ca}^{++}\left(\mathrm{GVB}^{++}, \mathrm{pH} 7.5\right)$, and the mixture was kept at $20^{\circ} \mathrm{C}$ or $28^{\circ} \mathrm{C}$ with gentle agitation. The viable cell number of the sample was determined by standard spread-plate technique on nutrient agar containing $0.1 \%$ of $\mathrm{MgCl}_{2}$. $6 \mathrm{H}_{2} \mathrm{O}$ after serial dilution in PBS. The same serum but previously heated at $50^{\circ} \mathrm{C}$ for $30 \mathrm{~min}$ in water bath was also used. In addition, to examine the requirement of divalent ions $\left(\mathrm{Ca}^{++}\right.$and $\mathrm{Mg}^{++}$) in serum bactericidal activity, these ions were removed from serum by chelation with 0.01-10 mM EDTA (ethylenediamine tetraacetic acid disodium salt) or EGTA (ethyleneglycol-bis $(\beta$ aminoethyl-ether)-tetraacetic acid). ${ }^{17)}$

Prior to the bactericidal assay, the agglutination titers of both unheated and heated serum were measured against formalinized antigens of ET7601 and ET-2 by a microtiter method.

\section{Pathogenicity Test}

Each fish species was injected intramuscularly (IM) with several doses of ET-7601 and ET-2 cultured on nutrient agar at $20^{\circ} \mathrm{C}$ for 2 days. After injection, fish were maintained in freshwater at $20^{\circ} \mathrm{C}\left(14^{\circ} \mathrm{C}\right.$ for rainbow trout $)$ and at $28^{\circ} \mathrm{C}$ for some experiments using eels and bluegill. Throughout the observation period of 2 weeks ( 3 weeks for rainbow trout), dead fish were examined bac. teriologically.

\section{Results}

\section{Survival in Normal Japanese Eel Serum}

Fig. 1 shows the sensitivities of ET-7601 and ET-2 strains to unheated or heated but undiluted serum of Japanese eels. In unheated serum, the ET-7601 strain survived without any decrease in viable number for $12 \mathrm{~h}$ of incubation at $20^{\circ} \mathrm{C}$, but at $28^{\circ} \mathrm{C}$ a delayed significant decrease in viable number occurred after $6 \mathrm{~h}(83 \%$ killed) and $12 \mathrm{~h}$ (99.7\% killed). Whereas, more than $99.9 \%$ of the cells of ET-2 strain were killed by serum even after $1 \mathrm{~h}$ at both $20^{\circ} \mathrm{C}$ and $28^{\circ} \mathrm{C}$. The removal of $\mathrm{Ca}^{++}$and $\mathrm{Mg}^{++}$by EDTA-treatment or $\mathrm{Ca}^{++}$ by EGTA-treatment from serum did not affect the bactericidal activity to ET-2 strain (data not shown). To heated serum, both strains were quite resistant irrespective of incubation temperature.

To examine the influence of culture-temperature on serum sensitivity, a nutrient broth culture of

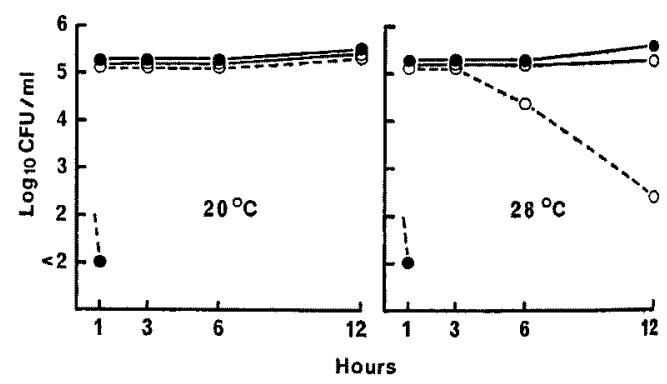

Fig. 1. Survival of $P$, anguilliseptica strains, ET$7601(O)$ and ET-2 (O), in Japanese eel serum at $20^{\circ} \mathrm{C}$ and $28^{\circ} \mathrm{C}$ : unheated serum (-.-), heated (at $50^{\circ} \mathrm{C}$ for $30 \mathrm{~min}$ ) serum (-).

Table 1. Effect of culture-temperature on sensitivity of ET-7601 strain to Japanese eel serum

\begin{tabular}{cccccc}
\hline \multirow{2}{*}{$\begin{array}{c}\text { Culture } \\
\text { temp. }\end{array}$} & \multicolumn{2}{c}{ Agglutinin titers of } & $\begin{array}{c}\text { Pathogenicity } \\
\text { to } \\
\text { Japanese eel }\end{array}$ & $\begin{array}{c}\text { Reaction } \\
\text { temp. }\end{array}$ & $\begin{array}{c}\text { Survival } \\
\text { rate }\end{array}$ \\
\hline $20^{\circ} \mathrm{C}$ & 128 & $<4$ & + & $20^{\circ} \mathrm{C}$ & $100 \%$ \\
\hline $28^{\circ} \mathrm{C}$ & 128 & 16 & + & $28^{\circ} \mathrm{C}$ & $2.2 \%$ \\
\hline
\end{tabular}

*1 Fish were IM-injected with $1 \times 10^{\circ} \mathrm{CFU} / 100 \mathrm{~g}$ at $20^{\circ} \mathrm{C}$

$* 2$ assayed after $12 \mathrm{~h}$-incubation 


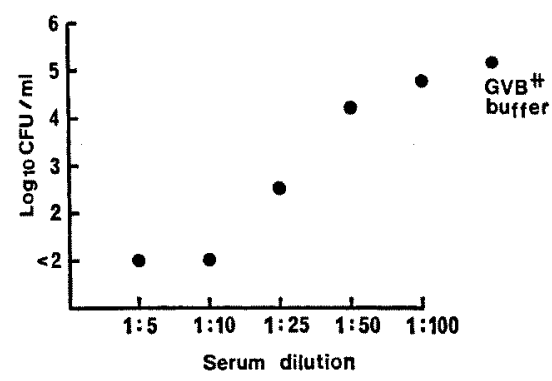

Fig. 2. Survival of ET-2 strain in diluted $(1: 5-1$ : 100) Japanese eel serum after incubation at $20^{\circ} \mathrm{C}$ for $6 \mathrm{~h}$.

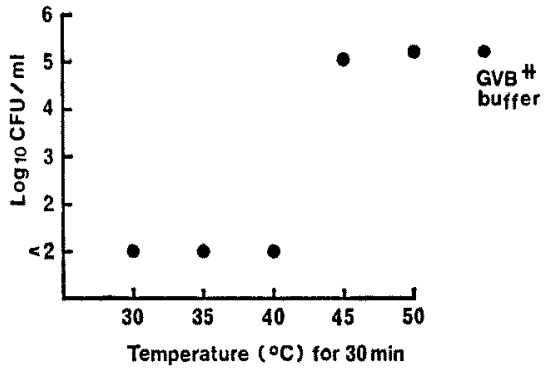

Fig. 3. Survival of ET-2 strain in heated (at $30-50^{\circ} \mathrm{C}$ for $30 \mathrm{~min}$ ) Japanese eel serum after incubation at $20^{\circ} \mathrm{C}$ for $6 \mathrm{~h}$.

Table 2. Resistance of 20 strains of $P$. anguilliseptica to Japanese eel serum-killing and pathogenicity to Japanese eel

\begin{tabular}{|c|c|c|c|c|c|}
\hline \multirow{2}{*}{ Strain } & \multirow{2}{*}{ Serotype } & \multicolumn{2}{|c|}{ Agglutinin titers of } & \multirow{2}{*}{$\begin{array}{l}\text { Sul vival } \\
\text { rate }(\%)^{* 1}\end{array}$} & \multirow{2}{*}{$\begin{array}{c}\text { Pathogenicity } \\
\text { to eel }{ }^{* 2}\end{array}$} \\
\hline & & Anti-K serum & Anti-O serum & & \\
\hline ET-7601 & $\mathbf{K}^{+}$ & 128 & $<4$ & 96 & + \\
\hline NCMB 1949 & $\mathrm{~K}^{+}$ & 128 & $<4$ & 54 & + \\
\hline $810314-6 L$ & $\mathrm{~K}^{+}$ & 256 & $<4$ & 62 & + \\
\hline $810314-4 \mathrm{~K} 1$ & $\mathrm{~K}^{+}$ & 256 & $<4$ & 98 & + \\
\hline EO-8104 & $\mathrm{K}^{+}$ & 256 & $<4$ & 67 & + \\
\hline ET-4 & $\mathrm{K}^{+}$ & 512 & $<4$ & 62 & + \\
\hline ET-11 & $\mathrm{K}^{+}$ & 512 & $<4$ & 88 & + \\
\hline NE-2 & $\mathrm{K}^{+}$ & 256 & $<4$ & 88 & - \\
\hline ME-1 & $\mathbf{K}^{+}$ & 512 & $<4$ & 100 & + \\
\hline ET-31 & $\mathrm{K}^{+}$ & 256 & $<4$ & 77 & + \\
\hline ET-2 & $\mathbf{K}^{-}$ & $<4$ & 128 & $<0.1$ & - \\
\hline RiC 1 & $\mathrm{~K}^{-}$ & $<4$ & 128 & 0.1 & - \\
\hline ET-7603 & $\mathbf{K}^{-}$ & $<4$ & 128 & $<0.1$ & - \\
\hline ET-7505 & $\mathbf{K}^{-}$ & $<4$ & 64 & $<0.1$ & - \\
\hline ET-7429 & $\mathbf{K}^{-}$ & $<4$ & 64 & 0.2 & - \\
\hline ET-7413 & $\mathrm{K}^{-}$ & $<4$ & 64 & 0.2 & - \\
\hline ET-82004 & $\mathrm{K}^{-}$ & $<4$ & 128 & $<0.1$ & - \\
\hline ET-7701 & $\mathrm{K}^{-}$ & $<4$ & 256 & 0.2 & - \\
\hline ET-7401 & $\mathrm{K}^{-}$ & $<4$ & 128 & $<0.1$ & - \\
\hline MEB-1 & $\mathrm{K}=$ & 32 & 32 & 1.7 & - \\
\hline$-1 a^{* 3}$ & $\mathrm{~K}^{+}$ & 512 & $<4$ & 50 & - \\
\hline$-1 b^{* 3}$ & $\mathbf{K}^{-}$ & $<4$ & 32 & $<0.1$ & - \\
\hline
\end{tabular}

ET-7601 strain at $20^{\circ} \mathrm{C}$ or $28^{\circ} \mathrm{C}$ for $48 \mathrm{~h}$ was reacted with unheated serum of Japanese eel at $20^{\circ} \mathrm{C}$ or $28^{\circ} \mathrm{C}$ for $12 \mathrm{~h}$ (Table 1). Although $\mathrm{O}$ specific agglutinin titer was detected in the $28^{\circ} \mathrm{C}$ culture, there were no differences between $20^{\circ} \mathrm{C}$ and $28^{\circ} \mathrm{C}$-cultures in $\mathrm{K}$-specific agglutinin titer, pathogenicity to Japanese eel, or sensitivity to eel serum.

In a separate series of tests, where the mixture of serum and ET-2 strain was reacted at $20^{\circ} \mathrm{C}$ for
$6 \mathrm{~h}$, more than $99.9 \%$ of the bacteria were killed by 10 -fold diluted or $40^{\circ} \mathrm{C}$-heated serum (Figs. 2, 3). However, the bactericidal activity of the serum was lowered by higher dilutions or temperatures.

The sensitivities of $10 \mathrm{~K}^{+}, 9 \mathrm{~K}^{-}$, and one $\mathrm{K}^{ \pm}$ strains of $P$. anguilliseptica to 10 -fold diluted serum of Japanese eel were examined after incubation at $20^{\circ} \mathrm{C}$ for $6 \mathrm{~h}$ (Table 2). The survival rate of each strain in unheated serum was expressed as per- 
centage against $100 \%$ survival in heated serum. The survival rates of $\mathrm{K}^{+}$strains were all higher than $54 \%$, whereas those of $\mathrm{K}^{-}$and $\mathrm{K}^{ \pm}$strains were less than $0.2 \%$ and $1.7 \%$, respectively. It was found in the experiment with MEB-1 strain that only $\mathrm{K}^{+}$type cells survived in unheated serum, but both types were recovered in heated serum. When each of the two derivatives prepared by pure culture was tested separately, the survival rates of $\mathrm{K}^{+}$(MEB-1a) and $\mathrm{K}^{-}$(MEB-1b) were $50 \%$ and less than $0.1 \%$, respectively. The IMinjection with a dose of $1 \times 10^{9} \mathrm{CFU} / 100 \mathrm{~g}$ proved that $9 \mathrm{~K}^{+}$strains were pathogenic to Japanese eel but one $\mathrm{K}^{+}(\mathrm{NE}-2), \mathrm{K}^{ \pm}$(MEB-1) and its derivatives (MEB-1a, MEB-1b), and $9 \mathrm{~K}^{-}$strains were not (Table 2).

\section{Effect of Antibody on Bactericidal Activity of Normal Serum}

Immune Japanese eel or rabbit serum, previously heated at $50^{\circ} \mathrm{C}$ (eel) or $56^{\circ} \mathrm{C}$ (rabbit) for $30 \mathrm{~min}$, was added to normal Japanese eel serum at ratio of $1: 1$, and the mixture was incubated with ET7601 strain at $20^{\circ} \mathrm{C}$. However, the bactericidal activity of the normal serum was not enhanced by the presence of antibody (data not shown).

\section{Survival in Other Fish Serum}

Fig. 4 shows the sensitivities of ET-7601 and ET-2 strains to both unheated and heated non-

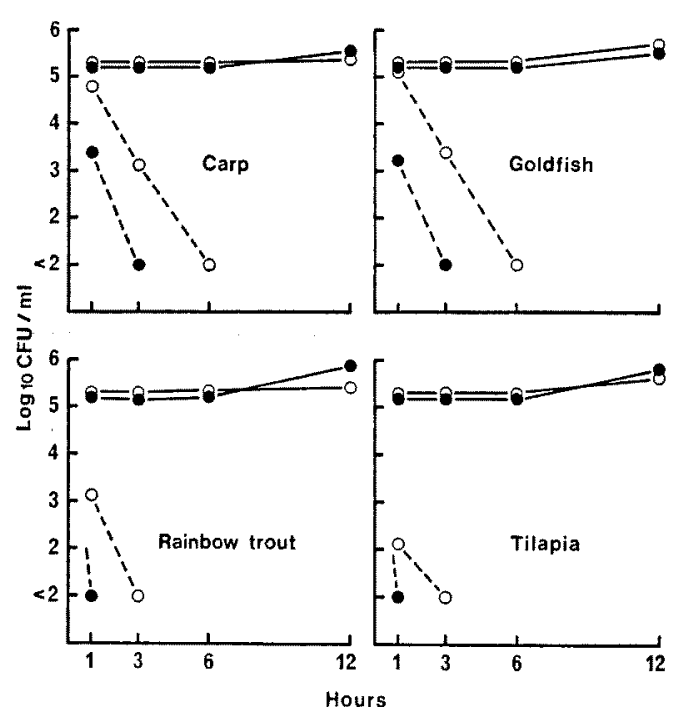

Fig. 4. Survival of ET-7601 (O) and ET-2 (o) strains in carp, goldfish, rainbow trout, and tilapia sera (1:5 dilution) at $20^{\circ} \mathrm{C}$ : unheated serum (--.), heated (at $50^{\circ} \mathrm{C}$ for $30 \mathrm{~min}$ ) serum $(-$ ). immune sera of carp, goldfish, rainbow trout, and tilapia. Each serum was 5 -fold diluted with $\mathrm{GVB}^{++}$, and the reaction was carried out at $20^{\circ} \mathrm{C}$. In every unheated serum, $99.9 \%$ or more cells of both strains were killed by $6 \mathrm{~h}$ of incubation, although ET-2 strain was more sensitive than ET7601 strain in all cases.

Fig. 5 shows the results with undiluted sera of bluegill and European eel when reacted at $20^{\circ} \mathrm{C}$ and $28^{\circ} \mathrm{C}$. The ET-7601 strain was almost perfectly resistant to unheated bluegill serum, but showed a temporary decrease in viable number in unheated European eel serum after $6 \mathrm{~h}$ at $20^{\circ} \mathrm{C}$. At $28^{\circ} \mathrm{C}$, the number of viable cells of ET-7601 in both unheated sera continuously decreased as in the serum of Japanese eel (Fig. 1).

\section{Agglutinin Titers of Normal Fish Sera}

As shown in Table 3, ET-7601 did not agglutinate in any of the unheated or heated sera (titer $<4$ ), while ET-2 was agglutinable at titers from 4 to 32 , with one exception of extremely high titer of 512-1024 to rainbow trout serum.

\section{Virulence to Fishes}

The results of pathogenicity test against seven fishes are shown in Table 4. Carp, goldfish, tilapia, and rainbow trout were all resistant to IMinjection of both ET-7601 and ET-2 strains even at the highest dose $\left(2 \times 10^{\circ} \mathrm{CFU} / 100 \mathrm{~g}\right)$ at $20^{\circ} \mathrm{C}$.

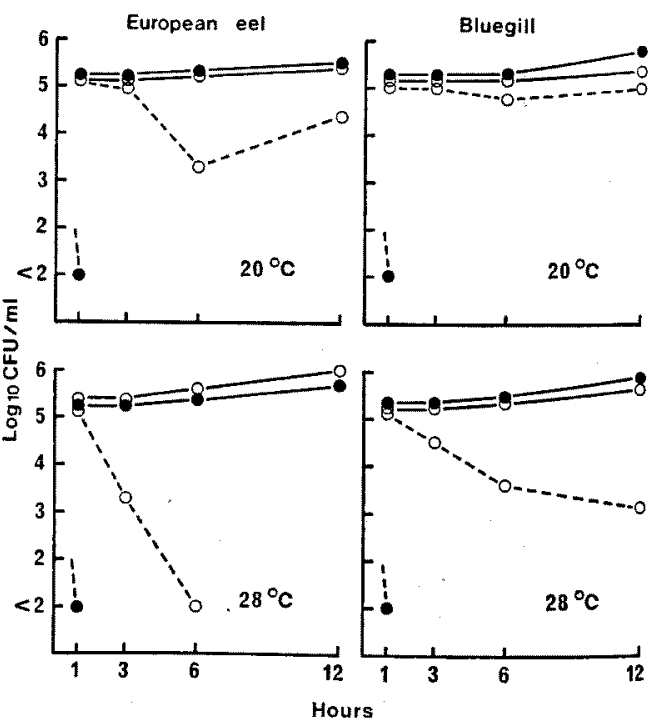

Fig. 5. Survival of ET-7601 (O) and ET-2 (0) strains in European eel and bluegill sera at $20^{\circ} \mathrm{C}$ and $28^{\circ} \mathrm{C}$ : unheated serum (--), heated (at $50^{\circ} \mathrm{C}$ for $30 \mathrm{~min}$ ) serum (-). 
Table 3. Agglutinin titers of fish sera used for bactericidal experiments

\begin{tabular}{|c|c|c|c|}
\hline \multicolumn{2}{|c|}{ Serum } & \multicolumn{2}{|c|}{$\begin{array}{c}\text { Agglutinin titers } \\
\text { against }\end{array}$} \\
\hline Fish & Treatment & $\underset{7601^{* 1}}{\text { ET- }}$ & ET-2*1 \\
\hline \multirow[t]{2}{*}{ Japanese eel } & unheated & $<4$ & 4 \\
\hline & heated*2 & $<4$ & 4 \\
\hline \multirow[t]{2}{*}{ European eel } & unheated & $<4$ & 32 \\
\hline & heated & $<4$ & 32 \\
\hline \multirow[t]{2}{*}{ Bluegill } & unheated & $<4$ & 4 \\
\hline & heated & $<4$ & 4 \\
\hline \multirow[t]{2}{*}{ Carp } & unheated & $<4$ & 16 \\
\hline & heated & $<4$ & 16 \\
\hline \multirow[t]{2}{*}{ Goldfish } & unheated & $<4$ & 4 \\
\hline & heated & $<4$ & 8 \\
\hline \multirow[t]{2}{*}{ Tilapia } & unheated & $<4$ & 8 \\
\hline & heated & $<4$ & 8 \\
\hline \multirow[t]{2}{*}{ Rainbow trout } & unheated & $<4$ & 1024 \\
\hline & heated & $<4$ & 512 \\
\hline
\end{tabular}

Table 4. Virulence of ET-7601 and ET-2 strains against fishes (IM-injection)

\begin{tabular}{|c|c|c|c|c|}
\hline \multirow{2}{*}{ Fish } & \multirow{2}{*}{$\begin{array}{l}\text { Water } \\
\text { temp. } \\
\left({ }^{\circ} \mathrm{C}\right)\end{array}$} & \multirow{2}{*}{$\begin{array}{c}\text { Injection } \\
\text { dose } \\
(\mathrm{CFU} / \\
100 \mathrm{~g})\end{array}$} & \multicolumn{2}{|c|}{$\begin{array}{l}\text { Number of fish } \\
\text { died/tested }\end{array}$} \\
\hline & & & $\begin{array}{l}\text { ET- } \\
7601\end{array}$ & ET-2 \\
\hline \multirow{5}{*}{ Japanese eel } & 20 & $2 \times 10^{9}$ & $5 / 5$ & $0 / 5$ \\
\hline & 20 & $2 \times 10^{7}$ & $5 / 5$ & \\
\hline & 20 & $2 \times 10^{8}$ & $3 / 5$ & \\
\hline & 20 & $2 \times 10^{5}$ & $0 / 5$ & \\
\hline & 28 & $2 \times 10^{9}$ & $0 / 5$ & $0 / 5$ \\
\hline \multirow{5}{*}{ Bluegill } & 20 & $2 \times 10^{9}$ & $5 / 5$ & $0 / 5$ \\
\hline & 20 & $2 \times 10^{2}$ & $5 / 5$ & \\
\hline & 20 & $2 \times 10^{8}$ & $5 / 5$ & \\
\hline & 20 & $2 \times 10^{5}$ & $1 / 5$ & \\
\hline & 28 & $2 \times 10^{8}$ & $0 / 5$ & $0 / 5$ \\
\hline \multirow{3}{*}{ European eel } & 20 & $2 \times 10^{8}$ & $3 / 5$ & $0 / 5$ \\
\hline & 20 & $2 \times 10^{8}$ & $0 / 5$ & \\
\hline & 28 & $2 \times 10^{9}$ & $0 / 5$ & $0 / 5$ \\
\hline Carp & 20 & $2 \times 10^{9}$ & $0 / 5$ & $0 / 5$ \\
\hline Goldfish & 20 & $2 \times 10^{9}$ & $0 / 5$ & $0 / 5$ \\
\hline Tilapia & 20 & $2 \times 10^{8}$ & $0 / 5$ & $0 / 5$ \\
\hline Rainbow trout & 14 & $2 \times 10^{9}$ & $0 / 5$ & $0 / 5$ \\
\hline
\end{tabular}

In contrast, Japanese eel, bluegill, and European eel were susceptible to ET-7601 strain at the same water temperature, with a minimum lethal dose of $2 \times 10^{8}, 2 \times 10^{5}$, and $2 \times 10^{8} \mathrm{CFU} / 100 \mathrm{~g}$, respectively. However, when kept at $28^{\circ} \mathrm{C}$ after injection with dose of $2 \times 10^{\circ} \mathrm{CFU}$, these fishes survived throughout the observation period of 2 weeks without causing apparent symptoms.

\section{Discussion}

It has been well investigated in human bacterial infections that some surface components of microorganisms contribute to interference with host defenses. ${ }^{18)}$ The works on $\mathrm{K}$ antigen of Escherichia coli have revealed that strains rich in $\mathrm{K}$ antigen are more resistant to complementmediated killing of human serum and phagocytosis than strains with little $\mathrm{K} \cdot{ }^{19-21)}$ MUNN et al. ${ }^{3)}$ demonstrated that the presence of a surface component (designated as A-layer or A-protein) as well as lipopolysaccharide (LPS) in virulent strains of Aeromonas salmonicida is associated with resistance of the organism to serum-killing of human, rabbit, and rainbow trout. This suggested that such a surface component would function as a protective barrier to access of serum bacteriolytic component (complement) to the cytoplasmic membrane.

The present study showed that $\mathrm{K}^{+}$strains of $P$. anguilliseptica displayed high resistance to the bactericidal action of Japanese eel serum (Table 2). Coupled this in vitro serum resistance with the previously reported in vivo persistance of $\mathrm{K}^{+}$strain in Japanese eels, ${ }^{18)}$ the $\mathrm{K}$ antigen-related resistance to serum-killing is possibly an important factor for the organism to spread systemically and produce fatal disease in susceptible animals. The bactericidal activity of Japanese eel serum was heat-labile at $45^{\circ} \mathrm{C}$ or $50^{\circ} \mathrm{C}$ and specific antibodyindependent. However, it was not identical to the complement system activated by alternative pathway, ${ }^{17)}$ since chelation of $\mathrm{Ca}^{++}$and $\mathrm{Mg}^{++}$ with EDTA did not inhibit the activity.

The correspondence between $\mathrm{K}$ antigen-related serum resistance and pathogenicity or virulence was also confirmed in other fish species. The sera of carp, goldfish, rainbow trout, and tilapia were able to kill the $\mathrm{K}^{+}$strain and these fishes were not susceptible to the organism (Fig. 4, Table 4). Whereas, the serum bactericidal power to $\mathrm{K}^{+}$ strain was much weaker in bluegill, and this fish species was highly susceptible (Fig. 5, Table 4). The serum bactericidal activity to virulent $\mathrm{K}^{+}$ strain of European eel was more effective than that of Japanese eel, and this may explain the fact that European eels are less susceptible than Japanese eels.

It was reported on $A$. salmonicida that A-layer lacking $\left(\mathrm{A}^{-}\right)$mutant could be readily obtained 
from initial $\mathrm{A}^{+}$population by culture at a high temperature $\left(30^{\circ} \mathrm{C}\right)$, and this mutation resulted in loss of the resistance to serum-killing and virulence. ${ }^{3,22)}$ A previous work confirmed that $\mathrm{K}^{-}$ strains of $P$. anguilliseptica had a higher optimum growth temperature than $\mathrm{K}^{+}$strains. ${ }^{23)}$ However, the cultivation of $\mathrm{K}^{+}$strain at a high temperature $\left(28^{\circ} \mathrm{C}\right)$ did not affect the $\mathrm{K}$ antigenicity, resistance to serum-killing, or pathogenicity (Table 1).

In the experiments with Japanese eel, European eel, and bluegill, a higher incubation or ambient water temperature $\left(28^{\circ} \mathrm{C}\right)$ lowered the resistance to serum-killing and virulence of $\mathrm{K}^{+}$strain of $P$. anguilliseptica (Figs. 1, 5, Table 4). This change is likely due to the increase in bactericidal or bacteriolytic activity of serum with the higher temperature, since the temperature of $28-30^{\circ} \mathrm{C}$ was optimal for the hemolytic activity to rabbit red blood cells of eel serum (data not shown). This temperature-dependency of serum bactericidal activity and reverse temperature-dependency of physiological activities of the pathogen ${ }^{24)}$ must be reflected in the seasonal changes in prevalence of red spot disease.

\section{Acknowledgements}

I wish to thank Professor K. Muroga, Fac. Appl. Biol. Sci., Hiroshima University, for his valuable suggestions and critical reading of the manuscript.

This work was partly supported by research grant (59760140) from the Ministry of Education.

\section{References}

1) G. A. Ingram: J. Fish Biol., 16, 23-60 (1980).

2) T. J. Trust, I. D. Courtice, A. G. Khouri, J. H. CROSA, and M. H. SCHIEWE: Infect. Immun., 34, 702-707 (1981).

3) C. B. MunN, E. E. Ishiguro, W. W. Kay, and T. J. TRust: Infect. Immun., 36, 1069-1075 (1982).
4) D. D. Ourth and E. A. Wilson: Dev. Comp. Immunol., 6, 579-583 (1982).

5) T. IIDA and H. Wakabayashi: Fish Pathol., 18, 77-83 (1983).

6) D. K. SAKAI: J. Fish Biol., 23, 457-466 (1983).

7) H. WAKabayashi and S. EguSA: Bull. Japan. Soc. Sci. Fish., 38, 577-587 (1972).

8) Y. Jo, K. Muroga, and K. ONIsHI: Fish Pathol, 9, 115-118 (1975).

9) S. C. Kuo and G. H. Kou: Report of the $\mathrm{ln}$ stitute of Fishery Biology of Ministry of Economic Affairs and National Taiwan University, 3, 19-23 (1978).

10) D. J. Stewart, K. Woldemariam, G. Dear, and F. M. Mochaba: J. Fish Diseases, 6, 75-76 (1983).

11) K. Muroga, Y. Jo, and M. Yano: Fish Pathol, 8, 1-9 (1973).

12) T. Nakal, K. Muroga, and H. Wakabayashl: Bull. Japan. Soc. Sci. Fish., 47, 699-703 (1981).

13) T. Nakal, K. Muroga, and H. WakabaYash: Bull. Japan. Soc. Sci. Fish., 48, 363-367 (1982).

14) T. Nakal and K. Muroga: Fish Pathol., 17, 147-150 (1982).

15) T. Nakai, K. Muroga, H. Y. Chung, and G. H. Kou: Fish Pathol., in press (1985).

16) T. NAKaI, Y. KaNemorr, K. NAKaJima, and K. MURoga: Fish Pathol., in press (1985).

17) M. Nonaka, N. Yamaguch, S. NatsuumeSAKAI, and M. TAKAHASHI: J. Immunol., 126, 1489-1494 (1981).

18) H. SMITH: Bact. Rev., 41, 475-500 (1977).

19) L. H. Muschel: Proc. Soc. Exp. Biol. Med., 103, 632-636 (1960).

20) A. A. GlYNN and C. J. Howard: Immunol, 18, 331-346 (1970).

21) C. J. Howard and A. A. GIYNN: Immunol, 20, 767-777 (1971).

22) E. E. Ishiguro, W. W. Kay, T. Ainsworth, J. B. Chamberlain, R. A. Austen, J. T. Buckley, and T. J. TRUst： J. Bacteriol., 148, 333-340 (1981).

23) K. Muroga, K. Satoh, and T. Nakai: Fish Pathol., 19, 193-196 (1984).

24) K. Muroga, T. Nakai, and T. Sawada: Fish Pathol., 12, 33-38 (1977). 